\title{
THE MEANING OF GRATIFICATION, MORAL CREDENTIAL, AND THE VALUE OF SELFLESSNESS ACTION IN VIOLATIONS COMMITTED BY A RESPECTED PERSON
}

\author{
Ni Made Martini Puteri', Hamdi Muluk², Amarina Ariyanto², Bagus Takwin² \\ ${ }^{1}$ Criminology Department, Faculty of Social and Political Science, Universitas Indonesia, \\ Jalan Margonda Raya, Pondok Cina, Beji, Kota Depok, Jawa Barat 16424 \\ ${ }^{2}$ Faculty of Psychology, Universitas Indonesia \\ Jalan Margonda Raya, Pondok Cina, Beji, Kota Depok, Jawa Barat 16424 \\ tinduk.nm@gmail.com
}

\begin{abstract}
This study aims to prove how kindness conducted by the group, the definition of violations and the value of doing good, can affect moral credential in the form of the leniency of punishment for corruptors. Sample 319 polices and doctors divided into two segments. This study uses a population-based survey experiment method. Participants divided into moral credential with the narrative noble duty, and non-moral credential with neutral narratives. Researchers require each participant to provide criminal punishment and social reactions to the vignette of violation cases due to receiving gratification without (study 1) and with group support (study 2). Statistical correlation test with Kendall's Tau-b finds that defining the behaviour of gratification influences punishment, the correlation shown in invisible victim is $r_{\tau}=.455, p=.000$, and visible victim, $r_{\tau}=.191, p=.003$, but there is no significant relationship between the values of selflessness action and defining the behaviour of gratification as a violation $\left(r_{\tau}=-.006, p=.922\right)$. Through the Mann Whitney $\mathrm{U}$ test it was found that the moral credential and nonmoral credential conditions do not affect the provision of informal social reactions to violators, both the perpetrators of gratification with invisible victims $(M d n=2), U=2757, p=.523$, and visible victims $(M d n=2)$, $U=2778.5, p=.575$, and also in a situation of gratification with group support, the perpetrators of gratification with invisible victims $(M d n=2), U=3419, p=.937$, and visible victims $(M d n=2), U=2978,5, p=.119$.
\end{abstract}

Keywords: moral credential; punishment; visible victim; groups; social reaction

\begin{abstract}
Abstrak
Penelitian ini bertujuan untuk membuktikan bagaimana kebaikan yang dilakukan oleh kelompok, definisi pelanggaran dan nilai berbuat baik, dapat mempengaruhi moral credential berupa keringanan hukuman bagi koruptor. Sampel 319 polisi dan dokter dibagi menjadi dua segmen. Penelitian ini menggunakan metode eksperimen survei berbasis populasi. Peserta dibagi menjadi moral credential dengan narasi tugas mulia, dan nonmoral credential dengan narasi netral. Peneliti mewajibkan setiap peserta untuk memberikan hukuman pidana dan reaksi sosial terhadap sketsa kasus pelanggaran karena menerima gratifikasi tanpa (studi 1) dan dengan dukungan kelompok (studi 2). Tes statistik Kendall's Tau-b menemukan bahwa pendefinisian perilaku gratifikasi mempengaruhi penghukuman, korelasi yang ditunjukkan pada korban yang tidak terlihat adalah $r_{\tau}=0,455, p=$ 0,000 , dan korban yang terlihat, $r_{\tau}=0,191, p=0,003$, namun tidak ada hubungan yang signifikan antara nilainilai tindakan tanpa pamrih dan mendefinisikan perilaku gratifikasi sebagai pelanggaran $\left(r_{\tau}=-0,006, p=0,922\right)$. Melalui uji Mann Whitney $U$ ditemukan bahwa moral credential dan kondisi non-moral credential tidak mempengaruhi reaksi sosial informal terhadap pelanggar, baik pelaku gratifikasi dengan korban yang tidak terlihat $(M d n=2), U=2757, p=0,523$, maupun korban yang terlihat $(M d n=2), U=2778,5, p=0,575$, dan juga dalam situasi gratifikasi dengan dukungan kelompok, pelaku gratifikasi dengan korban yang tidak terlihat $(M d n=2), U$ $=3419, p=0,937$, dan korban yang terlihat $(M d n=2), U=2978,5, p=0,119$.
\end{abstract}

Kata kunci: moral credential; hukuman; korban terlihat; kelompok; reaksi sosial

\section{INTRODUCTION}

Several of the most prominent corruption cases in Indonesia involve people with respectable profession and position, which is called by Benson and Simpson (2015) and Gottschalk (2017) as respectability and high social status people, including polices and 
doctors (Suara Pembaruan, 2015). However, after the judicial process, corruptors tend to receive a lesser sentence (Husodo, 2011). On the other side, a group of ordinary people often do not criticize the corruptor. They still perceive the corruptor as an admirable person and consider as a hero, so that the perpetrator deserves leniency, and people tend to forgive the mistakes (Sinaga, 2017). This condition reflects the signs of the punishment leniency toward perpetrator from a respectable position and profession.

To date, giving a light punishment for perpetrator from a respectable position, much explained by social status in the social dimension. The violation committed by respectable people is a part of White-Collar Crime or WCC (Alalehto, 2015). Gottschalk and Gunnesdal (2018) name it as occupational crime, a violation, conducted while taking advantage of legitimate position. Thus, this violation is perceived as a not breaking the law behaviour and hard-to-prove behaviour (Gottschalk, 2018), also perceived as harmless behaviour compared to Street Crime or SC (Alalehto, 2015). SC is a crime, involving property loss, occurred on the street, carried out with or without threat, and usually with violence. On the Street Crime case, such as theft, robbery and mugging (Xu \& Liu, 2015), the threat, victim, and loss are visible. On the other hand, the victims of White-Collar Crime involving professional and respectable group are unrecognized. Therefore, frequently, this crime is perceived as a lighter act because of the unrecognized victim (Henning, 2015). Thus, it can be concluded that the corruption, committed by respectable people will receive a formal reaction in the form of punishment and light informal social reaction because of perpetrator social status and the nature of the difficulties in proving the violation, and the invisible victim.

This research will explain how the psychological mechanism called moral credential function in the signs of the lesser sentence received by the perpetrator. According to the moral credential theory, each kindness and right action will be added in the moral saving value. When there is a surplus in moral saving value, the individual will perform the compensatory action (Jordan, Mullen \& Murnighan, 2011), such as violation. Furthermore, the history of individual's kindness action grows a sense of entitlement to commit a violation. Former researches prove that the increasing moral saving does not always come from individual's kindness action (Mazar \& Zhong, 2010; Khan \& Dhar, 2006; Schuldt \& Schwarz, 2010), but can come from imaginary good actions. Planning blood donor (Cascio \& Plant, 2015), imagining doing kindness, contemplating self-control not to commit violation even when there is an opportunity, are proved can grow a feeling of being a right person (Khan \& Dhar, 2006; Jordan, Mullen, \& Murnighan, 2011). The feeling as a good person without doing real good action called counterfactual transgressions (Mazar \& Zhong, 2010; Tiefenbeck, Staake, Roth, \& Sach, 2013).

A moral licensing qualitative study in Indonesia (Puteri, Muluk, \& Aryanto, 2018) find that police and doctor are included to the respectable profession in Indonesia. An individual with this profession tends to feel of being a right and moral person (counterfactual transgressions). Their work and action will be perceived as kindness, generosity, and always accompanied by a willingness to help. Therefore, counterfactual transgressions have occurred several times (multiple counterfactual transgression). An individual working as Police and Doctor will experience moral surplus. The moral surplus condition gives a chance for an individual to commit violation (Effron, Miller, \& Monin, 2012) without guilty feeling (Merritt, Effron, \& Monin, 2010) and worries about others views of themselves (Effron, Miller, \& Monin, 2012). For example, in treating a patient, a doctor gives a medication not based on patient's need, but there is an intention for earning commission from a pharmaceutical company (Chattopadhyay, 2013); however, the excellent action of healing patient cover 


\section{the Value of Selflessness Action in Violations}

Committed by a Respected Person

up the intention of earning a commission. Something similar happened in police institution, the funds for crime prevention are ironically collected from corruption which is beneficial for organization development (Newburn, 2015).

Violation will cause cognitive dissonance (Bandura, 2016) and guilty feeling for the perpetrator. Moral credential study shows that perpetrator builds moral rationalization, that is purposely defining violation behaviour as a non-violation (Braidley-Geist, King, Skorinko, Henl, \& Mckenna, 2010). The moral rationalization purposes to release perpetrator from guilty feeling and be rescued from punishment. They reinterpret behaviour so that a violation is perceived as an ambiguous behaviour and build a kindness behaviour track record (Effron \& Monin, 2010). Besides, they lower the moral limit for themselves and raise the moral limit for others so that they still appear having a high moral standard (Khan, 2011; Tsang, 2002). Even Barkan, Ayal, Gino, and Ariely (2012) identify an attempt by perpetrator to enact double distant mechanism, such as creating rules that can make them perceived as a person with kindness action and ethical so that they can judge others more cruelly. The perpetrator chooses the double distant mechanism strategy when the actors behave obviously unethical and, so the actors find it challenging to reinterpret the strategy. Furthermore, a moral credential study proves that moral credential can affect the leniency of punishment toward the perpetrator (BraidleyGeist dkk, 2010; Effron \&Monnin, 2010).

Re-interpretation process on violation behaviour's interpretation can occur with or without intention (Merritt, Effron, \& Monin, 2009; Monin \& Miller, 2001). According to Brown et al. (2011) perpetrator create a track record as a moral person purposely to avoid punishment in the future. Perpetrator purposely and deliberately build violation motives to be seen as legitimate behaviour, so that the violation of harming others does not appear real, and the perpetrator can get impunity (Merritt, Effron, Fein, Savitsky, Tuller, \& Monin, 2012).

The study from Kouchaki (2011) proves that an individual can interpret kindness conducted by groups as the kindness of each member of the group. A member of a group will feel that he is a moral person because of the goodness committed by his group so that he feels entitled to commit an offence. This sign called as vicarious moral licensing (Kouchaki, 2011). When individuals identify themselves with their group (in-group favouritism), there will be serial depersonalization of each group members, namely the in-group attribute becomes part of the self (Abbink \& Harris, 2019; Pratto \& Stewart, 2012) or in-group bias occurs (Everette, Faber, \& Crockett, 2015). Thus, deviations and malicious behaviour conducted by a member of the group evoke a threat to the entire group (Abrams, Palmer, Rutland, Cameron, \& Van de Vyver, 2013). Therefore, it is essential for group members always to maintain positivity in their group (Trepte \& Loy, 2017; Wagoner, Belavadi \& Jung, 2017); thus, it leads to positive selfidentification.

When a group member commit violation, the group will give a hard punishment or vice versa (Fousiani, Yzerbyt, Kteily, \& Demoulin, 2019). Research about Black Sheep Effect (BSE), describe that violation done by a group member will threatens group integrity, humiliate, so it deserves a more severe punishment (Cheng \& Huang, 2019; Rullo, Presaghi, \& Livi, 2015). Otherwise, research about the Devil Protection Effect (DPE) shows that the group give a lighter punishment for violation done by its member with the purpose of the group looks more positive, strong and solid (Stratton, 2007).

Indonesians consider that performing kindness with sincerity or selflessness is essential (Rahyono, 2011). If an individual performs kindness with sincerity, his kindness will not be counted to the value of moral saving, so, with sincerity or selflessness, $a$ 
moral credential in the form of the leniency of punishment will not occur. Otherwise, when an individual performs kindness and expects kindness in return, the individual who receives kindness is obligate to return the kindness (Mulyono, 2016). Therefore, an individual performing kindness and expecting kindness in return has an orientation to count his kindness to increase moral saving. Accordingly, they feel owning moral credential to commit a violation in the form of the leniency of punishment toward corruptors.

Indonesian Constitution No. 10/2001 concerning the Eradication of Corruption Crime states that a gratification is a form of corruption. However, the uncovering of several gratification cases in the media involving the polices and doctors show that the practice of delivering gifts to officials and professionals continues and is considered normal. In the medical profession, receiving gratuities from pharmaceutical companies and medical instruments is perceived as a standard practice (Mostert et al., 2011; Yousafzai, 2015). Police receiving gratuities will be perceived as a typical case and not considered as corruption and serious offences (Newburn, 2015).

Somadiyono (2014) believes that corruption in many judicial institutions in Indonesia is organizational culture. Corruption is not only in the mind of law enforcers, but mostly the group norms support this attitude. Groups that supposed to punish its members because of violating the norms, on the contrary, encourage the violation by creating norms supporting corruption (Gorsira, Steg, Denkers, \& Huisman, 2018). Corrupt behaviour supported by a group is called Unethical Pro-organizational Behaviour (UPB), a behaviour that is deliberately performed by members of an organization, to provide benefits for the organization or its members, and for both simultaneously (Umphress, Bingham, \& Mitchell, 2010; Tsiavia, 2016). The existence of group members committing or knowing the occurrence of violations plays a role as a cooffend (Free \& Murphy, 2013; Lantz, 2015; Lantz \& Hutchison, 2015). Therefore, violations are not defined as violations if many people commit to that behaviour. Thus, group members committing corruption are still declared as a moral and professional person because the violations are beneficial for the group.

Based on the description above, researchers conclude that Police and Doctors are eminent jobs, which results in significant moral savings. In performing their work, polices and doctors have the opportunity to commit corruption in the form of accepting gratuities. To avoid punishment, polices and doctors will interpret gratification as non-violation behaviour (Puteri, Muluk, \& Aryanto, 2018). The interpretation is possible because gratification is an ambiguous violation if it is related to the value of kindness action, selflessness, which is highly valued by the Indonesian people. Thus, it is very relevant if this study proves the moral credential signs in the form of giving light punishment to the offender receiving gratification with the subject of the professional groups, police and doctor. This research also completes the limitations of the previous study. This study improves the experimental setting in the laboratory, and consider the research context (Western and Eastern society; individual vs collective), as well as the perspective of the observer by proving that the moral credential symptom is universal in Eastern societies (collective) by taking the perspective of the actors.

This study aims to prove how moral credential in the form of punishment leniency for corruptors is influenced by action of group kindness, the definition of the violation and the value of performing kindness. This study tests the following main hypotheses:

1. There is a relationship between the definition of gratification and punishment for the perpetrator of gratification.

2. There is a significant relationship between the value of kindness action, selflessness 


\section{the Value of Selflessness Action in Violations}

Committed by a Respected Person

and defining gratification behaviour as a violation.

3. There is no difference between the moral credential (MC) and non-moral credential (Non-MC) groups in providing informal social reactions to perpetrators of gratification violations.

\section{METHOD}

\section{Research Design}

This study used a population-based survey experiment (Mutz, 2011), and the researchers divide this study into two segments, with a total of 319 participants, with police and doctor as professions. The research design in this study consisted of only two conditions of moral credential, moral credential narrative vs non-moral credential $\mathrm{x} 2$ (receiving gratification, invisible victim with group support vs visible victim and group support). Researchers manipulate variables in study 1 and 2. Manipulation is conducted in the form of giving a narration about the noble duties of a doctor or police officer and neutral narration. Then the researchers require the participants to design a punishment for the offence committed by the perpetrator (police/doctor). Each participant writes down the punishment for violation conducted by the figure in the narration, having the same profession as the participants.

\section{Participants}

Study 1

Researchers collect the data by contacting the intermediary person at the workplace of prospective participant. This method allows researchers to find potential participants according to the criteria. Researchers avoid a formal permit process because it is believed can have a significant impact on the participant's response. The head of the institution could give direction in responding to the questions.

The total number of participants in study 1 was 153 participants consisting of 72 polices $(47.1 \%)$ and 81 doctors (52.9\%). Ninety-five participants $(63.3 \%)$ are male, and three respondents did not give information about gender $(2 \%)$. One hundred nineteen $(77,8 \%)$ participants are in the largest age group, between 19-35 years old, as many as 25 participants $(16.3 \%)$ are in the age range of $36-50$ years, and five participants $(3.3 \%)$ are in the range of ages 51-65 years, and unknown age as much as four people (2.6\%). Most of the participants, as many as 126 participants $(82.4 \%)$ have a working experience of 1-15 years, 13 participants $(8.5 \%)$ have a working experience of 16-30 years, five participants (3.3\%) have working experience between 3145 years, and nine participants are unknown $(5.9 \%)$.

\section{Study 2}

Researchers collect the data in study 2 with a similar method to study 1 . At each workplace, the researcher has an intermediary who provides information about the availability of data collection and the possibility of approaching the participant. In study 2, the researchers divide the questionnaire through the intermediary and collect it again by coming directly or through a delivery service.

One hundred sixty-six people engage in this study, 67 participants $(40.4 \%)$ are police officer, and 99 participants $(59.65 \%)$ are doctors. There are 90 male participants $(54.2 \%)$, while 73 are female (44\%), and three of them did not give information about gender $(1.8 \%)$. As many as $93(56 \%)$ participants are between 19-35 years old, 55 people aged 3650 years $(33.1 \%), 13$ people aged 51-65 years (7.8\%), and unknown as many as five people (3\%). A number of 114 participants $(68.7 \%)$ have a working experience of 1-15 years, 37 participants $(22.3 \%) \quad 16-30$ years, 6 participants (3.6\%) 31- 45 years, and 9 participants $(5.4 \%)$ without explanation.

\section{Procedure}

\section{Study 1}

At each location of the data collection, the researchers distribute the questionnaire randomly. First, the number of potential participants in each location should be discovered to determine the number of questionnaires and narration should be 
distributed. The participants can randomly take the narrations and questionnaire (MC and non-MC) so that random procedure is completed. After an introduction about the study, the procedure of filling the questionnaire is giving personal data (with initials) and signing the informed consent. The narrative for the moral credential group contains a narrative about the noble duty of the Police / Doctor, whereas the non-moral credential group contains a neutral narrative about eating food contains iron and the police profession. Furthermore, the researcher requires the participants to provide punishment (criminal) and social reactions toward vignette of violation case in receiving gratification with the unclear condition of the victim (invisible victim) and exact victim condition (visible victim). The returning questionnaire is conducted direct after participants finished the distributed questionnaire.

\section{Study 2}

Study 2 has a similar procedure to study 1 . However, the difference was only in the vignette of violation receiving gratification cases. In the second study, there is a difference in the content of distributed narration. There is an additional statement about group members knowing about the violation (group support), with two victim conditions, visible and invisible. The researchers engage in returning the questionnaire process by picking up in the participant's place or by sending the filled questionnaire via email or using another service (courier).

\section{Measurement}

The sample size in this study was determined based on moral licensing research conducted by Blanken et al. (2014) with 63-150 participants in each study. This study determines that the minimum sample size in each study is 120 participants, according to the calculation of G Power $(d=.38)$ and meets the $95 \%$ power effect size.

The independent variable in this study is moral credential differentiated through the narrative about the noble duties of the Police / Doctor. The gratifications of violation cases vary based on two conditions, invisible vs visible victim (study 1). In study 2 , an additional condition about group support is added to the narrative, whereas the gratifications vary in two conditions invisible vs visible victim.

The dependent variable of this experimental research consists of (1) criminal punishment and (2) informal social reactions. This study uses the scale of punishment developed by Braun and Gollwitzer (2012) to measure criminal punishment. Six points of Likert scale ranged from 1-6, from 'strongly disagree' to 'strongly agree' was applied on this scale. Item example is "It must be ensured that the perpetrator (Police B) is punished". The high score reflects the high participants' willingness to provide severe punishment. The small score reflects the leniency of punishment for the offender. Two items used by Effron et al. (2018) represent the measurement of informal social reaction. The original instrument uses a range of seven Likert scales, while in this study only six, ranging from 'strongly disagree' to 'strongly agree', which is in line with the punishment scale of Braun and Gollwitzer (2012) An example of an item include "Police B is a morally honest person."

The moderator variables of this study are the level of social identification and the meaning of kindness action and selflessness. The researchers use the instrument from Cadinu and Reggiori (2002) to measure the level of social identification. This instrument consists of 4 items with a Likert scale of 1-7, ranging from 'strongly disagree' to 'strongly agree'. However, the researchers decide to use only three items that fit the research context and understanding in Indonesia. The item statement includes, "I feel close to my fellow policeman." The high score indicates a high level of identification.

Researchers construct instruments to measures the meaning of doing kindness with 


\section{the Value of Selflessness Action in Violations}

Committed by a Respected Person

selflessness. The instrument consists of 8 items, including "I .... the person I help will say thank you." The blank space should be filled with seven response scale, ranging from 'not demand' to 'demand'. The high score on the selflessness scale shows that the individual is kind, honest and selflessness, and will not count his kindness in credit on moral savings.

The results of the Confirmatory Factor Analysis (CFA) show that the items can explain the measured variables with a score above .7, except for the instrument for measuring the kindness and selflessness action, with a value of $\alpha=.688$. The researchers test the hypothesis using Kendall's Tau-b and Mann Whitney U correlation, to determine the differences between groups. The researchers decide to choose the variable test because the results of the normality test show that the sample is not normally distributed.

\section{RESULT AND DISCUSSION}

\section{Study 1}

In study 1, Kendall's tau-b correlation test shows a relationship between defining gratification and punishment for the perpetrator of gratification (hypothesis 1), which is proven to have a significant positive relationship. Kendall's tau-b correlation test also shows a positive relationship in both gratification violation condition, invisible and visible victim. The correlation shown in invisible victim is $r_{\tau}=.455, p<.05$, and visible victim, $r_{\tau}=.191, p<.05$.

The second hypothesis of the first study state that the value of doing kindness with selflessness has a relationship with the definition of gratification behaviour in violation. This hypothesis is not proven. A gratification without group support, the value of doing kindness with selflessness does not affect how polices and doctors define gratification behaviour as a violation $\left(r_{\tau}=\right.$ $.006, p=.922)$. The third hypothesis states that there is no difference between the moral credential (MC) and non-moral credential (non-MC) groups in providing informal social reactions to violators. This hypothesis is proven. The statistic result shows that there is no difference between the non-moral credential and moral credential groups in providing informal social reactions to invisible victims $(M d n=2), U=2757, p=$ .523 , and visible victims $(M d n=2), U=$ $2778.5, p=.575$.

\section{Study 2}

The relationship between defining gratification and punishment for the perpetrator of gratification (hypothesis 1), is once more confirmed in study 2 . From Kendall's tau-b correlation test, it is found that there is a significant positive relationship between defining gratification and punishment for the invisible victim $\left(r_{\tau}=.458\right.$, $p<.05)$, and gratification with visible victims $\left(r_{\tau}=.283, p<.05\right)$, for violations that received group support.

The second hypothesis states that under group support the value of doing kindness with selflessness can influence the definition of gratification. This hypothesis is not proven $\left(r_{\tau}\right.$ $=-.036, p=.570)$. The third hypothesis states that there is no difference between the moral credential (MC) and non-moral credential (non-MC) groups in providing informal social reactions to violators. This hypothesis is proven correct. In a situation of gratification with group support, there is no significant difference between the non-moral credential and the moral credential in giving informal social reactions to the invisible victim $(M d n=$ $2), U=3419, p=.937$, as well as in the gratification condition with visible victims $(M d n=2), U=2978.5, p=.119$.

The difference between study 1 and 2 was in the vignette of gratification cases. In study 1, participants are given a gratification vignette without information about group members (police and doctor) who know about the violation. In contrast, participants in study 2 were given a gratification vignette with additional information that group members know and committed the same offence. There are three hypotheses in this research. Figure 1 shows the model and results of this study. 


\begin{tabular}{|c|c|c|c|c|c|c|}
\hline \multicolumn{4}{|c|}{ Moral Credential } & & & \\
\hline \multicolumn{4}{|c|}{$\begin{array}{c}\text { Condition } \\
\end{array}$} & & \multicolumn{2}{|c|}{ Punishment in Group } \\
\hline Narration & $\begin{array}{l}\text { Roles on } \\
\text { cases }\end{array}$ & Study 1 & Study 2 & \multirow{4}{*}{ No correlation } & \multirow{2}{*}{$\begin{array}{l}\text { Informal } \\
\text { social } \\
\text { reaction }\end{array}$} & \multirow[b]{2}{*}{$\begin{array}{l}\text { Criminal } \\
\text { sanction }\end{array}$} \\
\hline \multirow[t]{2}{*}{$\begin{array}{l}\text { Noble task } \\
\text { (Mc) }\end{array}$} & \multirow[t]{2}{*}{$\begin{array}{l}\text { - Police } \\
\text { - Doctor }\end{array}$} & \multirow{2}{*}{$\begin{array}{l}\text { Gratification } \\
\text { on invisible } \\
\text { victim }\end{array}$} & \multirow{2}{*}{$\begin{array}{l}\text { Gratification } \\
\text { on invisible } \\
\text { victim with } \\
\text { group support }\end{array}$} & & & \\
\hline & & & & & $\begin{array}{ll}\text { - } & \text { High } \\
\text { - } & \text { Low }\end{array}$ & $\begin{array}{ll}\text { - } & \text { Severe } \\
\text { - } & \text { Mild }\end{array}$ \\
\hline \multirow[t]{2}{*}{$\begin{array}{l}\text { Neutral } \\
\text { (Non-Mc) }\end{array}$} & \multirow[t]{2}{*}{$\begin{array}{l}\text { - Police } \\
\text { - Doctor }\end{array}$} & \multirow[t]{2}{*}{$\begin{array}{l}\text { Gratification } \\
\text { on visible } \\
\text { victim }\end{array}$} & \multirow[t]{2}{*}{$\begin{array}{l}\text { Gratification } \\
\text { on visible } \\
\text { victim } \\
\text { without group } \\
\text { support. }\end{array}$} & & \multicolumn{2}{|c|}{ Correlated } \\
\hline & & & & \multirow{2}{*}{$\begin{array}{l}\text { Kindness } \\
\text { action with } \\
\text { selflessness }\end{array}$} & \multirow{2}{*}{ No correlation } & \multirow{2}{*}{$\begin{array}{l}\text { Meaning of } \\
\text { Gratification }\end{array}$} \\
\hline & & & & & & \\
\hline
\end{tabular}

Figure 1. Result of Hypothesis Testing

In testing hypothesis 1 , both studies show that the relationship between defining gratification and punishment for the gratification perpetrator has a significant positive relationship. As participants, polices and doctors define gratification as an offence and not an offence. This definition affects criminal punishment against the perpetrator of the violation. The relationship is positive meaning that the more the participants agree on the statement that gratification is ethic and law violation, also corruption, the more the participants agree in giving severe criminal penalties.

The evidence for hypothesis 1 can be explained that: first, the polices and doctors define gratification as a violation and not a violation. The definition of gratification as not a violation means that it is not a violation of the professional ethic codes, violation of the law of gratification, corruption, and define that it is acts that do not harm anyone. This attitude aims to gain the advantage of lighter sentences and avoid imprisonment. According to Braidley-Geist et al. (2010), the effort to define gratification as a violation and not a violation is a form of moral rationalization. Individuals perform moral rationalization to avoid guilty feeling and prevent themselves from being punished. The method used includes reinterpreting the behaviour so that the violation is seen as ambiguous behaviour and using a track record of good behaviour (Effron \& Monin, 2010), or lowering morale standards for self, and raising the moral boundary for others so that this person appears more moralistic (Khan, 2011; Tsang, 2002).

Second, the finding is that participant having narration with invisible victim gratification will give a weak punishment for gratification behaviour, so that the perpetrator can define the violation as not a violation to get the lesser sentence, the most beneficial to him. In the absence of victims and threat, the gratification of violation is not too noticeable, and it perceives as a mild violation (Fredericks, McComas, \& Weatherby, 2016). Thus, violations conducted by professional and respectable groups are often perceived as a lighter violation because the victim is invisible (Henning, 2015). Referring to Stratton (2007), when an individual commits a gratification violation with the invisible victim, it is likely that the group will only impose light punishment using the Devil Protection Effect (DPE) mechanism.

On the other hand, the condition of gratification with visible victims strengthens criminal punishment. The existence of victims complicates rationalization (Burkey \& Bensel, 2015; Burke \& Tomlinson, 2016; 


\section{the Value of Selflessness Action in Violations} Committed by a Respected Person

Laurin, 2018) and neutralization (Kaptein \& van Helvoort, 2019) and clarifies the disadvantage aspects (Herber, 2013). This study proves that in the case of gratification with group support, the definition of a gratification violation affects the punishment of the offender. However, in gratification violations with group support, the condition of the victim's presence (invisible vs visible) affects the punishment intensity. The group of the polices and doctors will provide severe punishment for their members who receive gratuities using the Black Sheep Effect (BSE) mechanism (Cheng \& Huang, 2019; Rullo, Presaghi, \& Livi, 2015).

Group arrange the severe punishment of group members as a group effort to prevent the effect of one bad apple on the barrel (Gino, Ayal \& Ariel, 2009). It means that if a member of the group commits an offence, it will harm the overall group image. When individuals receive gratification with visible victims, this condition is interpreted by the group as the inability of the perpetrator to maintain the confidentiality of the cocoon, failure to build compartmentalization, failure in separating the life inside outside the cocoon, and failure to give a good impression of being a member of society (Anand et al., 2005; Johnson et al., 2016). Therefore, in violations with visible victims with group support, the group punishes the members severely, because the group consider that the perpetrator, the smallest unit of the cocoon, threatens the cocoon with committing on corruption in the form of receiving gratification.

The hypothesis 2 states that the value of doing good without selflessly has a relationship with defining gratification behaviour as a violation. The second hypothesis is rejected. Researchers explain the rejections with three possible reasons. First, the value of doing good without selflessly, which has been considered an essential value for Indonesian society (Rahyono, 2011) may no longer play an essential role in Indonesian society. Researchers also consider the second possibility, that the sample of this study is a professional group in the Jabodetabek area, which reflects individuals in a collective society, but think and feel like individuals in an individualist society (Triandis, 2018). This idiocentric phenomenon is discoverable in educated, affluent, have the nomadic experience, which profoundly reflects the participants' profile in this study. Therefore, researchers suggest for further research to consider bigger sample size, and consider the locations outside Jabodetabek, to obtain participants with various background. Third, the CFA value might contribute to the rejection of the second hypotheses. CFA (Confirmatory Factor Analysis) value of the meaning of kindness action with selflessness is less than 7 (.688). This result proposes the indicators re-formulation about the meaning of kindness action with selflessness to Indonesian people.

Hypothesis 3 states that there is no difference between the moral credential (MC) and nonmoral credential (non-MC) groups in providing informal social reactions to offenders. This hypothesis is accepted. In gratification without group support (study 1), there is no significant difference between the non-moral credential and moral credential groups in giving informal social reactions to the perpetrator with invisible victim $(M d n=$ 2), $U=2757, p=.523$, and visible victims $(M d n=2), U=2778,5, p=.575$. In a situation of gratification with group support (study 2), there is no significant difference between the non-moral credential and moral credential groups in providing informal social reactions to the perpetrators of gratification with invisible victims $(M d n=2), U=3419, p=$ .937 , and visible victims $(M d n=2), U=$ $2978,5, p=.119$.

Moral credential (having moral savings from kindness) does not affect providing informal social reactions to the perpetrator of the gratuity violation. The participants receiving the neutral narrative (non-Moral Credential) and the narrative about the noble profession of police and doctor (moral credential condition) give the same informal social reaction. They 
continue to declare their group members who accepted gratification as moral and professional people. This condition reflects (1) Pre-violation justifications and postviolation justifications (Shalvi, Gino, Barkan, \& Ayal, 2015). Pre-violation justifications are conditions when the perpetrator redefines his violation as behaviour that can be forgiven. Besides, the perpetrator gains post-violation justifications in the form of compensatory behaviour with the aim that his behaviour can be forgiven. (2) Violation of gratification with group support is corrupt behaviour and potential to become a culture in an organization (Al-Jundi, Shuhaiber, \& AlEmara, 2019; Hechanova et al., 2014). Groups create norms that support corrupt behaviour (Vadera \& Pratt, 2013; World Development Report, 2015), which is known as Unethical Pro-organizational Behaviour (UPB). UPB is a violation that is intentionally committed by members of an organization, to provide benefits for the organization or its members or to benefit both (Tsiavia, 2016; Umphress, Bingham, \& Mitchell, 2010). Group members committing or knowing the occurrence of violations are perceived as co-offenders (Free \& Murphy, 2013; Lantz, 2015; Lantz \& Hutchison, 2015). Thus, the perpetrator and the group do not define gratification as a violation because many people make the same mistakes. Therefore, group members committing corruption are still declared as moral and professional people because the violations are beneficial for the group.

\section{CONCLUSION}

This research proves that there is a correlation between violation definition, presence of the victim, and punishment. Perpetrator and group give inconsistent definition toward gratification behaviour. In particular, it can be proved that moral credential is weakening on the leniency of punishment on gratification violation with group support, where group member who did violation with visible and invisible victim condition will get harsher punishment, like Black Sheep Effect mechanism. On the other hand, the moral credential condition does not affect the informal social reaction toward the perpetrator. Group keep assessing its members who receive gratification as a moral and professional person. If during this time, a corruptor can avoid punishment because gratification they received, based on selflessness value, their behaviour cannot be equated with corruption. However, this research has managed to prove that ulterior motive value does not correlate with gratification interpretation as a violation. Therefore, receiving gratification does not correlate with cultural practices of respecting others, but must be interpreted as a value of bad intention, so it deserved severe punishment.

\section{REFERENCES}

Abrams, D., Palmer, S. B., Rutland, A., Cameron, L., \& Van de Vyver, J. (2013). Evaluation and reasoning about normative and deviant ingroup and outgroup member: Development of the black sheep effect. Developmental Psychology, 50 (1), 258-270. doi: 10.1037/a.0032461.

Abbink K., \& Harris, D. (2019). In-group favouritism and out-group discrimination in naturally occurring groups. PLoS ONE 14(9): $\mathrm{e} 0221616$. doi:10.1371/journal.pone.0221616.

Al-Jundi, S. A., Shuhaiber, A., \& Al-Emara, S. S. (2019). The effect of culture and organisational culture on administrative corruption. Int. J. Economics and Business Research, 18(4), 436-451. doi: 10.1504/IJEBR.2019.103096

Alalehto, T. (2015). White collar criminals: The state of knowledge. The Open Criminology Journal, 8, 28-35. doi: 10.2174/1874917801508010028.

Anand, V., Ashforth, B. E., \& Joshi, M. (2005). Business as usual: The acceptance and perpetuation of corruption in organizations. Academy of Management 


\section{the Value of Selflessness Action in Violations}

Committed by a Respected Person

Executive, 9(4), 9-23. doi: 10.5465/AME.2004.13837437

Bandura, A. (2016). Moral disengagement: How people do harm and live with themselves. New York,NY: Macmillan.

Barkan, R., Ayal, S., Gino, F., \& Ariely, D. (2012). The pot calling the kettle black: Distancing response to ethical dissonance. Journal of Experimental Psychology: General. doi: 10.1037/a0027588.

Benson, M. L., \& Simpson, S. S. (2015). Understanding white-collar crime: An opportunity perspective. Routledge, NY: New York.

Blanken, I., Van de Ven, N., Zeelenberg, M., \& Meij., M. H. C. (2014). Three attempts to replicate the moral licensing effect. Social Psychology, 45(3), 232-238. doi: 10.1027/1864-9335/a000189.

Braidley-Geist, J. C., King, E. B., Skorinko, J., Hebl, M. R., \& McKenna, C. (2010). Moral credentialing by association: The importance of choice and relationship closeness. Social Psychology Bulletin, 36 (11), 1564-1575. doi: 10.1177/0146167210385920.

Braun, J., \& Gollwitzer, M. (2012). Leniency for out-group offenders. European Journal of Social Psychology, 42, 883892. doi: 101002/ejps.1908.

Brown, R. P., Tamborski, M., Wang, X., Barnes, C. D., Mumford, M. D., Connelly. S., \& Devenport, L. D. (2011). Moral credentialing and the rationalization of misconduct. Ethics Behavior. 21(1), 112. doi:10.1080/10508422.2011.537566.

Burke, R. J., \& Tomlinson, E. C. (2016). Crime and corruption in organizations: Why it occurs and what to do about it. In C. L. Cooper \& R.J. Burke (Eds.), Psychological and behavioral aspect of risk. Routdlege Taylor and Francis. Retrieved from
https://www.routledge.com/Crime-andCorruption-in-Organizations-Why-ItOccurs-and-What-To-Do-About/BurkeTomlinson/p/book/9781138381056.

Burkey, C. R., \& Bensel, T. (2015). An examination and comparison of rationalizations employed by solo and cooffending female sex offenders. Violence and Gender, 2(3). doi: 10.1089/vio.2015.0018

Cadinu, M., \& Reggiori, C. (2002). Discrimination of low-status outgroup: The role of ingroup threat. European Journal of Social Psychology, 32, 501515. doi: 10.1002/ejsp.105

Cascio, J., \& Plant, E. A. (2015). Prospective moral licensing: Does anticipating doing good later allow you to be bad now? Journal of Experimental Social Psychology, 56, 110-116. doi: 10.1016/j.jesp.2014.09.009.

Chattopadhyay, S. (2013). Corruption in healthcare and medicine: Why should physicians and bioethicists care and what should they do? Indian Journal of Medical Ethics, 10(3), 153-159. doi: 10.20529/IJME.2013.049.

Cheng, H. Y., \& Huang, K. P. (2019). Salute to Black Sheep: The legitimate of workplace bullying from the perspective of organizational cohesive affinity and organizational competitiveness. The International Journal of Organizational Innovation, 12(2). Retrieved from http://www.ijoi-online.org/

Effron, D., Markus, H. M., Jackman, L. M., Muramoto, Y., \& Muluk, H. (2018). Hypocrisy and culture: Failing to practice what you preach receives harsher interpersonal reactions in independent (vs. interdependent) cultures. Journal of Experimental Social Psychology, 76, 371384. doi: 10.1016/j.jesp.2017.12.009

Effron, D. A., Miller, D. T., \& Monin, B. (2012). Inventing racist roads not taken: 
The licensing effect of immoral counterfactual behaviors. Journal of Personality and Social Psychology, 1-18. doi: 10.1037/a0030008.

Effron. D. A., \& Monin, B. (2010). Letting people off the hook: When do good deeds excuse transgressions? Personality and Social Psychology Bulletin, 36(12), 1618-1634.

doi:

$10.1177 / 0146167210385922$.

Everett, C. J., Faber, N., \& Crockett, M. (2015). Preferences and beliefs in ingroup favoritism. Frontiers in Behavioral Neuroscience (9),15. doi: 10.3389/fnbeh.2015.00015.

Ousiani, K., Yzerbyt, V., Kteily, N-M., \& Demoulin, S. (2019). Justice reactions to deviant ingroup members: In group identity threat motivates utilitarian punishments. British Journal of Social Psychology, (58), 869-893. doi: 10.1111/bjso.12312

Free, C., \& Murphy, P. R. (2013). The ties that bind: the decision to co-offend in fraud. Contemporary Accounting Research, 32(1). doi: 10.1111/1911-3846.12063.

Fredericks K. A., McComas, R. E., Weatherby, G.A. (2016). White collar crime: recidivism, deterrence, and social impact. Forensic Res Criminol Int J, 2(1):5-14. 10.15406/frcij.2016.02.00039.

Gino, F., Ayal, S., \& Ariely, D. (2009). Contagion and differentiation in unethical behavior: the effect of one bad apple on the barrel. Psychology of Science, 20 (3), 393-398. doi: 10.1111/j.14679280.2009.02306.x.

Gorsira, M., Steg, L., Denkers, A., \& Huisman, W. (2018). Corruption in organizations: Ethical climate and individual motives. Journal of
Administrative $\quad$ Science 8(4). doi:10.3390/admsci8010004

Gottschalk, P. (2017). Entrepreneurs in whitecollar crime: A convenience perspective. International Journal of Entrepreneurial Knowledge, 5(2), 47. doi: 10.1515/ijek2017-0010.

Gottschalk, P., \& Gunnesdal, L. (2018). White-Collar Crime in the Shadow Economy Lack of Detection, Investigation and Conviction Compared to Social Security Fraud. doi:10.1007/978-3-31975292-1

Henning, P. J. (2015). Is deterrence relevant in sentencing white-collar criminals? (Rev.27). Retrieved from Wayne State University, Digital Commons Website: http://digitalcommons.wayne.edu/lawfrp/ 100.

Hechanova, R. M., Melgar, I., Falguera, P. Z., \& Villaverde, M. (2014). Organizational culture and workplace corruption in government hospitals. Journal of Pacific RIM Psychology,8(2), 62-70. doi: 10.1017/prp.2014.5.

Herber, A. (2013). Good versus bad? Victims, offenders and victim-offenders in Swedish crime policy. European Journal of Criminology, 11(4), 410-428. doi: $10.1177 / 1477370813503920$.

Husodo, A. T. (2011). Evaluasi dan roadmap penegakan hukum KPK 2012-2015. Jakarta: Indonesia Corruption Watch.

Johnson, A. E. W., Ghassemi, M. M., Nemati, Niehaus, K. E., Clifton, D. A., \& Clifford, G. D. (2016). Machine learning and decision support in critical care: The issues of compartmentalization, corruption, and complexity involved in collection and preprocessing of critical care data. Proceedings of the Institute of Electrical and Electronics Engineers, 104(2). doi: 10.1109/JPROC.2015.2501978. 


\section{the Value of Selflessness Action in Violations}

Committed by a Respected Person

Jordan, J., Mullen, E., \& Murninghan, J. K. (2011). Striving for the moral self: The effects of recalling past moral action on future moral behavior. Personality and Social Psychology Bulletin, 20 (10), 701713. doi: 10.1177/0146167211400208.

Kaptein, M., \& van Helvoort, M. (2019). A model of neutralization techniques. Deviant Behavior, 40(10), 1260-1285. doi: 10.1080/01639625.2018.1491696

Khan, L., \& Dhar, R. (2006). Licensing effect in consumer choice. Journal of Marketing Research, 43, 259-266. doi: 10.1509/jmkr.43.2.

Khan, U. (2011). When doing good makes it okay to be bad? New directions in licensing research. Advances in Consumer Research, 39, 81-84. Retrieved from https://www.acrwebsite.org/

Kouchaki, M. (2011). Vicarious moral licensing: The influence of other's past moral actions and moral behavior. Journal Pers Social Psychology, 101 (4), 702-715. doi: 10.1037/a0024552.

Lantz, B. (2015). Co-offender ties and the criminal career. Journal of Research in Crime and Delinquency, 52(5). doi: $10.1177 / 002242781557675$

Lantz, B., \& Hutchison, B. (2015). Cooffender ties and the criminal career: The relationship between co-offender group structure and the individual offender. Journal of Research in Crime and Delinquency 2015, 52(5). doi: $10.1177 / 0022427815576754$

Laurin, K. (2018). Inaugurating rationalization: Three field studies find increased rationalization when anticipated realities become current. Psychological Science, 24(4). doi: $10.1177 / 0956797617738814$

Mazar, N., \& Zhong, C. B. (2010). Do Green product make us better people?
Psychological Science. doi: 10.1177/0956797610363538.

Merritt, A. C., Effron, D. A., \& Monin, B. (2010). Moral self-licensing: When being good frees us to be bad. Social and Personality Psychology Compass, 4(5), 344-357. doi: 10.1111/j.17519004.2010.00263.x.

Merritt, A. C., Effron, D. A., Fein, S., Savitsky, K. K., Tuller, D. M., \& Monin, B. (2012). The strategic pursuit of moral credentials. Journal of Experimental Social Psychology, 48, 774777. doi: 10.1016/j.jesp.2011.12.017.

Monin.B. \& Miller, D. A. (2001). Moral credentials and the expression of prejudice. Journal of Personality and Social Psychology, 81 (1), 33-43. doi: 10.1037//0022-3514.81.1.33.

Mostert, S., Sitaresmi, M.N., Njuguna, F., Van Beers, E.J., \& Kaspers, G. J.L. (2011). Comentary effect of corruption on medical care in low-income countries. Pediatric Blood Cancer. doi: 10.1002/pbc.

Mulyono, A. (2016). Pengaruh aspek kultur hukum terhadap perkembangan tindak pidana gratifikasi di indonesia. Jurisprudentie, $\quad 3(2)$. doi: 10.24252/jurisprudentie.v3i2.2604.

Mutz, D. C. (2011). Population Based-Survey Experiment. Princeton, NJ: Princeton University Press

Newburn, T. (2015). Literature review: police integrity and corruption (Research Report Her Majesty's Inspectorate of Constabulary Inspecting Policing in Public Interest). Retrieved from Criminal Justice Inspectorates websites: https://www.justiceinspectorates.gov.uk/ hmicfrs/wp-content/uploads/picliterature-review.pdf

Pratto, F., \& Stewart, A. (2012). Social Dominance Theory. In Daniel J. Christie 
(ed.), The Encyclopedia of peace psychology $\left(1^{s t} e d\right)$. Blackwell Publishing. doi: 10.1002/9780470672532.wbepp253

Puteri, N. M. M, Muluk, H., Ariyanto, A. A. (2018). Seeking context for theory enforceability of moral licensing effect in collective culture society: When surplus moral lead law enforcers to get involved in corruption. In A. A. Ariyanto, $\mathrm{H}$. Muluk, P. Newcombe, F. P. Piercy, E. K. Poerwandari, \& S. H. R. Suradijono (Eds), Diversity in Unity: Perspectives from Psychology and Behavioral Sciences. doi:10.1201/9781315225302.

Rahyono, F. X. (2011). The concept of fairness as expressed in Javanese proposition: A study of cultural wisdom. Makara, Sosial Humaniora, 15 (1), 21-28. doi: 10.7454/mssh.v15i1.891.

Rullo, M., Presaghi, F., \& Livi, S. (2015) Reactions to ingroup and outgroup deviants: An experimental group paradigm for black sheep effect. PLoS One, $\quad$ 10(5): $\quad$ 0125605. doi:10.1371/journal.pone.0125605

Schuldt, J. P., \& Schwarz, R. (2010). The "organic" path to obesity? Organic claims influence calorie judgments and exercise recommendations. Judgment and Decision Making, 5 (3), 144-150. Retrieved from http://journal.sjdm.org/10/10509/jdm105 09.pdf.

Shalvi, S., Gino, F., Barkan, R., \& Ayal, S. (2015). Self-Serving Justifications: Doing Wrong and Feeling Moral. Current Directions in Psychological Science, 24 (2), 125-130. doi: $10.1177 / 0963721414553264$.

Sinaga, E. K. (2017, June 8). Siti Fadilah: Saya pemilik bintang maha putra tetapi ditahan bersama pencopet dan pencuri. Tribunnews.com. Retrieved from http://www.tribunnews.com/nasional/201 7/06/08/siti-fadilah-saya-pemilik- bintang-maha-putra-tetapi-ditahanbersama-pencopet-dan-pencuri.

Somadiyono, S. (2014). Police corruption: Influenced factors and suggested control in Indonesian police department. Journal of Law, Policy and Globalization, 24. doi: 10.2139/ssrn.2408434

Stratton, J. (2007). Social identification and the treatment of in-group deviants: The black sheep effect. (Doctoral Dissertation, University of South California, California). Retrieved from http://digitallibrary.usc.edu/cdm/ref/colle ction/p15799coll127/id/517169.

Suara Pembaruan. (2015, January 28). Ini hasil tangkapan polri selama 13 tahun berdiri. Suara Pembaruan. Retrieved from http://sp.beritasatu.com/home/inihasil-tangkapan-polri-selama-13-tahunberdiri/76300.

Tiefenbeck, V., Staake, T., Roth, K., \& Sach, O. (2013). For better or for worse? Empirical evidence of moral licensing in behavioral energy conservation campaign. Energy policy 57, 167-171. doi: 10.1016/j.enpol.2013.01.021.

Trepte, S., \& Loy, L. S. (2017). Social identity theory and self-categorization theory. In P. Rössler, C. A. Hoffner, \& L. van Zoonen (Eds.), The international encyclopedia of media effects. doi: 10.1002/9781118783764.wbieme0088.

Triandis, H. C. (2018). Individualism and collectivism. Abingdon: Routledge. https://doi.org/10.4324/9780429499845.

Tsiavia, N. (2016). Unethical ProOrganizational Behavior (UBP): Concept and study evolution. Science Journal of Business and Management, 4(2), 34-41. doi: 10.11648/j.sjbm.20160402.13.

Tsang, J.A. (2002). Moral rationalization and integration of situational factors and psychological processes in immoral 


\section{the Value of Selflessness Action in Violations}

Committed by a Respected Person

behavior. Review of general Psychology, 6 (1), 25-50. doi:10.1037.//10892680.6.1.25.

Umphress, E. E., Bingham, J. B., \& Mitchell, M. S. (2010). Unethical behavior in the name of the company: The moderating effect of organizational identification and positive reciprocity beliefs on unethical pro-organizational behavior. Journal of Applied Psychology, 95, 769-780. doi: 10.1037/a0019214.

Vadera, A. K., \& Pratt, M. G. (2013). Love, hate, ambivalence, or indifference? A conceptual examination of workplace crimes and organizational identification. Organization Science, 24, 172-188. doi: 10.2307/23362106.
Wagoner, J. A., Belavadi, S., \& Jung, J. (2017). Social identity uncertainty: Conceptualization, measurement, and construct validity. Self and Identity, 16(5), 505-530. doi: 10.1080/15298868.2016.1275762.

Yousafzai, A. W. (2015). Corruption in medical practice: where do we stand? Journal Ayub Med Coll Abbottabad, 27(3), 515-516. Retrieved from https://ayubmed.edu.pk/jamc/index.php/j amc/article/download/255/71.

Xu, J., \& Liu, J. (2015). Crime and punishment in China. In Wesley G. Jennings (ed.), The Encyclopedia of crime and punishment. Malden and Oxford: Wiley-Blackwell.

DOI: 10.1002/9781118519639.wbecpx173. 